\title{
KONTROVERSI KESAKSIAN PEREMPUAN: MENGURAI TAFSIR KESAKSIAN PEREMPUAN DALAM AL-QUR'AN
}

\author{
Naqiyah Mukhtar \\ STAIN Purwokerto \\ Jl. Jend. Ahmad Yani No 40 A. Purwokerto. \\ Email:naqiyah.mukhtar@gmail.com
}

\begin{abstract}
Abstrak
Saksi adalah orang yang hadir dalam suatu sengketa hukum untuk memberi keterangan berkaitan dengan peristiwa hukum yang dialaminya berkaitan dengan orang yang berperkara. Dalam hal perempuan sebagai saksi, terdapat kontroversi di kalangan para ulama dalam hal nilai kesaksian, cakupan kesaksian, dan hukum mempersaksikannya. Sementara, disimpulkan bahwa jika teks diinterpretasikan secara tekstual, maka nilai kesaksian perempuan adalah separuh kesaksian laki-laki, dan hal ini hanya mencakup hal-hal yang berkaitan dengan harta benda. Adapun hukum mempersaksikannya hanya sebagai anjuran. Akan tetapi, jika teks diinterpretasikan secara kontekstual, maka nilai kesaksian perempuan sama dengan kesaksian laki-laki. Dalam tulisan ini saya berargumen bahwa kesaksian perempuan menurut al-Qur'an sama dengan kesaksian laki-laki, baik ditafsirkan secara tekstual maupun secara kontekstual, baik dalam hal yang berkaitan dengan harta benda maupun yang berhubungan dengan masalah $\hat{h} u d \bar{u} d$. Adapun mengenai hukum mempersaksikannya, secara umum al-Qur'an menggunakan kata yang berbentuk 'amr sehingga dapat dipahami sebagai perintah.
\end{abstract}

Kata kunci: saksi, nilai kesaksian, perempuan, hukum Islam, tafsir al-Qur'an

\begin{abstract}
A witness is someone who attends in a legal dispute to give information regarding an incident that he/she experiences related to someone that has a law suit. As far as women are concerned, there are some controversies among Muslim scholars concerning women as witnesses in Islamic law; it is related to the value of women as witnesses, the scope of law that women can bear witness, and the legal status of their testimony. This paper argues that it is tentatively concluded that if the texts are textually interpreted, then the testimony of a woman on property cases is valued only half than that of a man and the woman's attendance is recommended. However if the texts are contextually analyzed, then the value of a female witness is equal to that of a male. The writer argues that according to the Holy Qur'an, the testimony of a woman, textually or contextually is equal to that of a man both on property cases and hudud. Regarding the legal status or the woman's attendance to bear witness, Qur'anic verses generally use $a m r$ so this can be considered as a command, not only a recommendation.
\end{abstract}

Kata kunci: witness, value of witness, woman, Islamic law, Qur'anic exegesis

\section{A. Pendahuluan}

Kata شهد yang terdiri atas deri\{vasi huruf د ڤ menunjuk pada makna hud'ūr (hadir), 'ilmu (mengetahui), dan i'lām (pemberitahuan). ${ }^{1}$ Dalam berbagai bentuknya, kata ini dalam alQur'an disebut 160 kali. Adapun kata saksi dalam al-Qur'an yang disebut 
dengan syahīd berasal dari kata syahida (al-syuhūd dan al-syahādah) yang berarti hadir serta menyaksikan baik dengan mata kepala maupun dengan kecerdasan akal (pengetahuan). ${ }^{2}$ Kata syahìd menurut alAşfihānī, berarti hadir dan menyaksikan. Al-syahādah menurut al-Jurjānī dalam إخبار عن عيان بلفظ الشهادة في الفي الفي

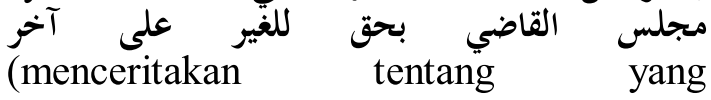
dilihat/disaksikannya dengan ucapan kesaksian di majlis hakim dengan haqq (yakin) untuk yang lain dalam rangka mengalahkan yang lain). ${ }^{3} \mathrm{Jadi}$, saksi adalah orang yang hadir serta menyaksikan baik dengan mata kepala maupun dengan pengetahuannya yang kemudian dapat dijadikan saksi baik di hadapan hakim maupun bukan di hadapan hakim.

Ada beberapa persoalan yang sering diperbincangkan kaitannya dengan kesaksian perempuan. Pertama, menurut jumhūr ulamā nilai kesaksiandua perempuan sebanding dengan satu lakilaki, sekalipun ada juga yang menyatakan bahwa kesaksian perempuan sama dengan kesaksian laki-laki. Kedua, mengenai cakupan kesaksian perempuan yang menurut kalangan Maliki, Syafi'i, dan Hanbali hanya terbatas pada hal-hal yang berhubungan dengan harta benda. Namun, menurut kalangan Hanafiah, kesaksian perempuan mencakup segala hal, selain qişāş dan hudūd. Bahkan, menurut kalangan Żāhirī kesaksian perempuan meliputi bidang apapun, tanpa kecuali. Ketiga, mengenai hukum mempersaksikan (khususnya dalam transaksi hutang piutang dan atau keuangan), ada ulama yang menyatakan bahwa hukumnya wajib, di samping ada yang menganggap hanya sebagai anjuran (sunat) saja. Keempat, bagaimana ayat-ayat al-Qur'an menyebut tentang kesaksian perempuan? Keempat hal tersebut akan dibahas dalam tulisan ini.

\section{B. Kesaksian Perempuan Separuh Kesaksian Laki-laki.}

Pada umunya dikatakan bahwa nilai kesaksian perempuan adalah separuh kesaksian laki-laki. Hal ini dikemukakan di antaranya oleh kalangan ulama klasik, sebagaimana yang dinyatakan oleh Umul Baroroh, ${ }^{4}$ para mufasir, sebagaimana dikemukakan oleh Yunahar Ilyas, ${ }^{5}$ dan Zaitunah Subhan. ${ }^{6}$ Argumen yang dikemukan adalah:

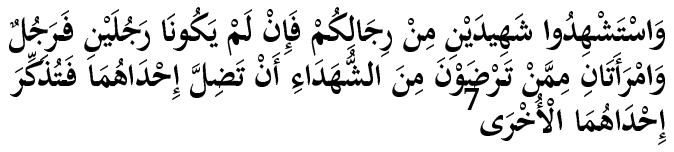

Hadis Nabi yang berbunyi,

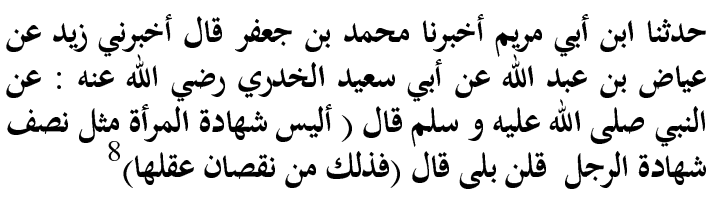

Hadis ini menceritakan bahwa Nabi s.a.w. bersabda "bukankah kesaksian perempuan seperti setengah kesaksian laki-laki?. Mereka (perempuan) berkata: "ya", Nabi bersabda "hal itu karena perempuan kurang akalnya." Hadis di atas sebenarnya disampaikan ketika Nabi akan melaksanakan shalat hari raya (idul fitri dan idul adha). Apabila hadis ini akan diterima, maka harus dibatasi maknanya dalam hal-hal yang sangat sempit. Perempuan kurang menggunakan aktivitas akalnya, bukan kurang kemampuannya, dalam situasi tertentu, misalnya, karena sibuk dengan kehamilan, melahirkan, dan menyusui. Perempuan dapat juga diberi kekurangan "tugas-tugas keagamaan," bukan keberagamaan, seperti ketakwaan dan ketaatan, misalnya, dalam waktuwaktu tertentu seperti ketika menstruasi. ${ }^{9}$

Argumen lainnya mengapa nilai kesaksian perempuan separuh laki-laki menurut Zaitunah Subhan berdasarkan hasil penelitiannya terhadap beberapa karya tafsir $^{10}$ adalah sebagai berikut: a. sebab yang bersifat kodrati, yaitu pelupa, ${ }^{11}$ emosional, dan pemikirannya kurang dari pada laki-laki. b. Sebab yang ada pada diri perempuan, yaitu kemungkinan adanya kekuatan luar yang akan memaksanya untuk memberikan kesaksian palsu. ${ }^{12}$ c. Kurang berpengalaman dalam transaksi bisnis. ${ }^{13}$ Dengan dasar dan argumen di atas tampaknya sangat kuat pendapat yang 
menyatakan nilai kesaksian perempuan separuh laki-laki. Meskipun demikian, apakah ayat dan hadis yang dijadikan dasar normatif itu memang harus dipahami demikian? Dan apakah kondisi perempuan secara kodrati sebagaimana yang dipersepsikan di atas? Juga, apakah kondisi eksternal dan pengalaman perempuan saat ini sebagaimana yang digambarkan di atas? Jika jawaban dari semua pertanyaan di atas ya, maka tidak perlu dipertanyakan kalau nilai kesaksian perempuan separuh kesaksian laki-laki. Lalu bagaimana dengan pendapat lainnya?

\section{Nilai Kesaksian Perempuan Sama Dengan Kesaksian Laki-Laki.}

Berbeda dengan pendapat mayoritas ulama, pendapat lain menyatakan bahwa nilai kesaksian perempuan sama dengan nilai kesaksian laki-laki. Dasarnya sama dengan yang dikemukakan ulama sebelumnya, yakni Q.S. al-Baqarah (2) : 282, hanya saja ayat tersebut tidak dipahami secara tekstual, malainkan secara kontekstual. Zaitunah Subhan, misalnya, menyatakan bahwa bila perempuan yang akan menjadi saksi itu matang dan berpengalaman dalam bisnis seperti Khadijah (istri Nabi), maka dapat dipakai formula $1: 1$ sebagai alternatif. ${ }^{14}$ Hal yang senada juga dikemukakan oleh Yunahar Ilyas, walaupun ia memberi catatan bahwa lebih baik jika tetap menggunakan formula 1 : 2 untuk antisipasi bila salah satunya mendapatkan hambatan sehingga tidak bisa hadir pada saat diperlukan kesaksiannya. ${ }^{15}$

Zaitunah Subhan tampaknya mempunyai persepsi, bahwa bunyi teks (ayat dan hadis) di atas demikian sesuai dengan kondisi umum saat ayat diturunkan. Karena itu, jika perempuan yang dijadikan saksi itu matang dan berpengalaman (tidak sebagaimana umumnya perempuan Arab saat ayat diturunkan), maka tidak lagi harus 1:2. Sedangkan Yunahar Ilyas tidak mengkaitkan nilai 1:2 itu, dengan kondisi perempuan saat ayat diturunkan, tetapi menghubungkannya dengan kondisi perempuan, yang mempunyai hambatan reproduksi sehingga dapat membatasinya untuk berbisnis. ${ }^{16}$ Mengenai rekomendasinya agar tetap menggunakan formula 1:2 sekalipun perempuan yang akan dijadikan saksi itu telah matang, dalam rangkamengantisipasi jika ada halangan ketika diperlukan kesaksiannya, sebenarnya dapat pula diperlakukan bukan hanya kepada perempuan, karena laki-laki pun tidak mesti terjamin tidak akan mendapatkan halangan.

Dengan demikian, dapat disimpulkan bahwa kesaksian perempuan menurut suatu pendapat adalah satu banding dua dari laki-laki, karena laki-laki mempunyai kelebihan dari perempuan atau berdasarkan pertimbangan pada terbatasnya pengalaman perempuan dalam bidang bisnis, sesuai dengan kondisi obyektif masyarakat Arab saat ayat diturunkan, bukan karena diskriminasi atau inferioritas perempuan. Sedangkan pendapat lainnya menyatakan bahwa nilai kesaksian perempuan sama dengan lakilaki, karena saat ini kondisi perempuan telah berubah, dengan terbiasanya menangani hal transaksi bisnis dan keuangan, sehingga diperlukan penafsiran ulang secara kontekstual terhadap Q.S. alBaqarah (2) : 282 yang dijadikan dalil normatif tersebut.

\section{Bidang Kesaksian Perempuan \\ 1. Kesaksian Perempuan Terbatas pada Harta Benda}

Kesaksian perempuan hanya terbatas pada hal-hal yang berhubungan dengan harta benda seperti dinyatakan oleh kalangan Maliki, ${ }^{17}$ Syafi' $i,{ }^{18}$ dan Hanbali. Dalil yang diajukan mereka berupa dalil nakli dan akli. Dalil al-Qur'an yang dimaksudkan adalah Q.S. al-Țalāq (65): 2.

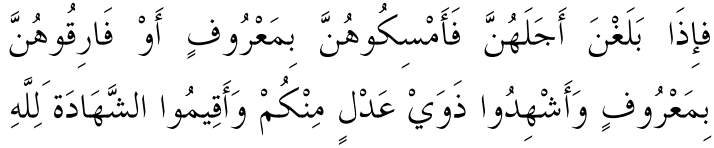




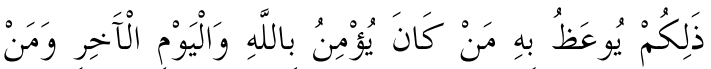

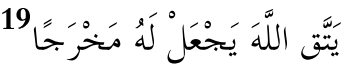

Ayat 2 surah al-T,alāq ini dipahami sebagai perintah untuk menjadikan saksi laki-laki yang adil dalam pernikahan, sehingga perempuan dilarang melakukannya. Teks ayat tersebut berbicara mengenai talak dan rujuk, bukan dalam pernikahan secara umum, sehinggaseharusnya dipahami bahwa yang diperintahkan untuk dipersaksikan kepada dua orang saksi yang adil adalah dalam kedua hal tersebut. Masalahnya, apakah saksi itu harus laki-laki? Ayat tersebut memang menggunakan kata yang berbentuk muźakkar (laki-laki), walau dalam bahasa Arab, tidak selalu kata-kata yang berbentuk muźakkar hanya dimaksudkan untuk laki-laki.

Selain ayat tersebut, Hadis 'Imrān bin Huşain, riwayat Ạ̣mad bin Hanbal juga dijadikan dasar, yaitu:

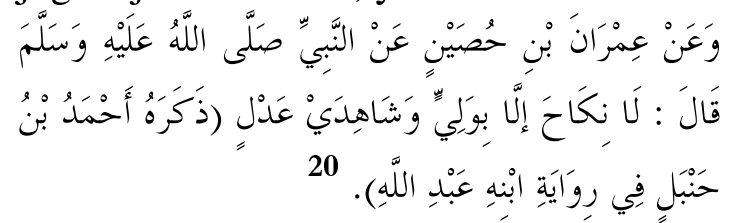

Hadis ini dipahami bahwa pernikahan dapat dikatakan sah jika disaksikan oleh dua orang saksi laki-laki yang adil.

Selain itu, seringkali digunakan juga argumen yang seolah-rasional, bahwa perempuan pada dasarnya tersembunyi, pemalu, dan jarang keluar rumah sehingga jika diperkenankan untuk menjadi saksi dalam hal-hal yang berkaitan dengan hak-hak anggota tubuh (huqūq al-abdān), seperti pernikahan, akan mengurangi kesempurnaan kondisi tersebut. Padahal, logika tersebut bisa digunakan sebaliknya, yakni pada dasarnya perempuan sebagai manusia "sama" dengan laki-laki, sehingga tidak perlu dibedakan dalam hal persaksian sepanjang ia mempunyai kemampuan dan integritas yang dapat dipertanggungjawabkan.

\section{Kesaksian Perempuan Mencakup Segala Hal, Selain Qişāş dan Huidūd.}

Menurut pendapat kalangan ulama Hanafiyah, kesaksian perempuan tidak hanya berkaitan dengan harta benda, tetapi mencakup segala hal, selain qișasş dan hudūd. ${ }^{21}$ Dalil yang diajukan adalah Q.S. al-Baqarah (2): 282:

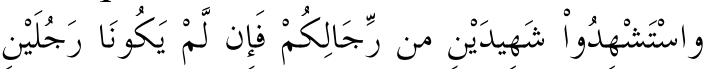

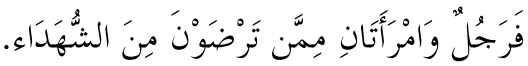

Ayat ini menunjukkan makna umum sehingga perempuan juga dapat menjadi saksi bersama laki-laki dalam segala bidang, kecuali untuk hal-hal yang memang disebut secara khusus, yaitu qișās, dan hudūd. Selain ayat di atas, kalangan Hanafiyah menggunakan qiyās bahwa khabar dari perempuan secara mandiri, tanpa laki-laki dapat diterima. Hal ini jelas tidak berkaitan dengan harta. Selanjutnya, kalangan Hanafiyah mengemukkan dalil 'aqli, bahwa perempuan mempunyai kemampuan (ahliyyah) dalam hal kesaksian.

Adapun kaitannya dengan bidang hudūd, M. Quraish Shihab mengutip pernyataan al-Zuhri, bahwa telah berlalu masa Rasul dan kedua khalifah sesudah beliau, kebiasaan tidak menerima persaksian wanita dalam saksi-saksi yang bersifat hudūd.22 Ini menurut M. Quraish Shihab karena sejak semula al-Qur'an dan Sunnah bermaksud menghindarkan wanita dari tempat-tempat mesum, apalagi menyaksikan kedurhakaan yang sangat buruk. Kalaupun ada yang menyaksiakannya, maka biarlah mereka itu lelaki, itupun diharapkan mereka tidak menyaksikannya, kerena mereka juga diharapkan tidak berkunjung ke tempattempat yang bejat. ${ }^{23}$

\section{Kesaksian Perempuan Meliputi Bidang Apapun}

Berbeda dengan pendapat mayoritas ulama dan ulama Hanfiyyah, kalangan Żāhiriyyah menyatakan bahwa kesaksian perempuan meliputi bidang apapun, tanpa kecuali walau nilainya 
hanya 2:1 dari kesaksian laki-laki. Argumentasi yang diajukan adalah Q.S. al-baqarah (2): 282 sebagaimana telah disebutkan di atas. Menurut kalangan Żāhir̄̄ ayat tersebut menunjukkan kebolehan perempuan menjadi saksi bersama laki-laki dalam segala hal sesuai dengan makna zahir ayat. ${ }^{24}$

Dari beberapa pendapat di atas dapat disimpulkan bahwa ulama berbeda pendapat dalam hal apa perempuan dapat menjadi saksi. Sebagain ulama (dari kalangan Mālikī, Syāfi'ì, dan Hạbalī) membolehkan hanya dalam hal yang berkaitan dengan harta benda, sementara kalangan Hanafi membolehkan dalam segala hal selain qișāș dan hudūd, bahkan kalangan Żāhirī membolehkannya dalam hal apapun tanpa kecuali.

\section{E. Hukum Kesaksian (Perempuan)}

Mengenai hukum kesaksian perempuan ada beberapa pendapat; ada yang mengatakan wajib sunnah, dan ada yang mengatkan haram. Kalangan ulama yang menyatakan wajib mengajukan dalil Q.S. al-Baqarah (2) : 282,

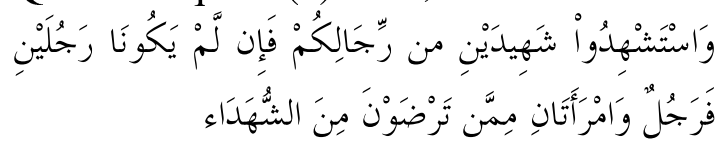

Menurut 'Ațā', Ibnu Juraij, al-Nakha'î', dan Ibnu Jarīr al-T,abarī, fi' il 'amar dalam ayat tersebut sebagai kata perintah yang berimplikasi hukum wajib. ${ }^{25}$ Sedangkan menurut jumhūr fuqah $\bar{a}^{\prime}$ ayat di atas walaupun menggunakan kata 'amr menunjukkan anjuran (nadb) saja. Dalam kenyataannya mayoritas umat Islam di negara-negara Islam tidak mencatat dan tidak mengharuskan adanya saksi dalam masalah hutang piutang. Kalau hal ini diwajibkan maka akan menyulitkan umat Islam, padahal Nabi diutus untuk membawa agama yang lurus dan mudah. ${ }^{26}$ Berbeda dengan dua pendapat di atas, al- Hasan, al-Sya'bī, al-Ḥakam, dan Ibnu 'Uyaynah, menyatakan bahwa ayat 282 surah al-Baqarah di atas sebenarnya menunjukkan wajib, tetapi kemudian di- nasakh oleh ayat sesudahnya yaitu Q.S. alBaqarah (2) : $283 .^{27}$

\section{F. Kesaksian Perempuan dalam al- Qur'an}

Para ulama mengajukan dalil alQur'an ayat 282 surah al-Baqarah dan ayat 2 surah al-T,alāq dalam hal kesaksian perempuan, sebagaimana telah disebutkan pada bagian sebelumnya. Pada bagian ini akan dibahas beberapa ayat yang menyinggung tentang kesaksian, di antaranya adalah yang berkaitan dengan harta benda seperti hutang piutang/jual beli (Q.S. al-Baqarah (2) : 282), wasiat (Q.S. al-Ma'idah (5) : 106-107), dan menyerahkan harta anak yatim (Q.S. anNisa' (4) : 6), kemudian mengenai menceraikan atau merujuk istri (Q.S. alJumu'ah (62) : 2), hal yang berkaitan dengan had menuduh orang berbuat zina (Q.S. an-Nur (24) : 4) dan menuduh istri berbuat zina (li'an) (Q.S. an-Nur (24) : 69), keharusan menjadi saksi dengan adil (Q.S. an-Nisa' (4) :135 dan Q.S. alMa'idah (5) : 8) dan reward surga bagi pelakunya (Q.S. al-Ma'arij (70) : 33), serta anggota tubuh akan menjadi saksi kelak di hari pembalasan (Q.S. an-Nur (24) : 24).

\section{Saksi yang Berkaitan dengan Harta Benda}

a. Saksi Ketika Transaksi Jual Beli

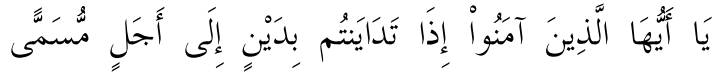

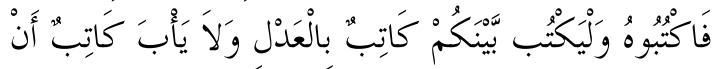

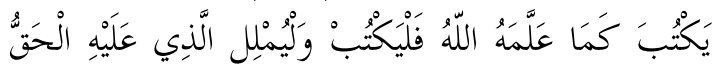

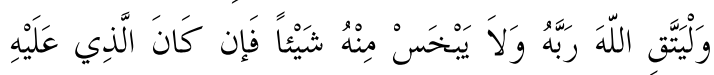

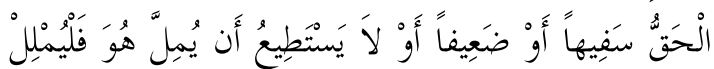

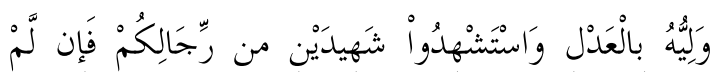

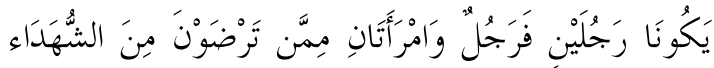

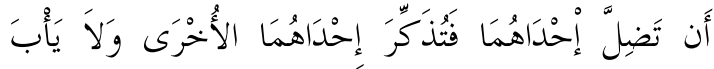

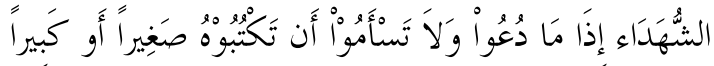

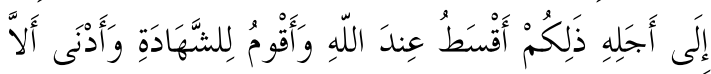

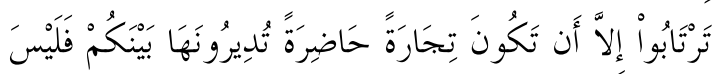

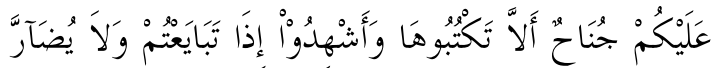




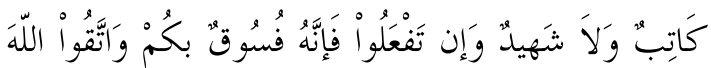

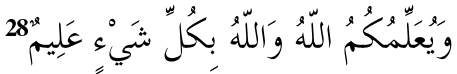

Ayat di atas mengandung beberapa hal yang berkaitan dengan saksi hutang piutang yaitu: 1) perintah untuk menuliskan hutang piutang, 2) perintah kepada penulis (hutang) untuk mencatatnya dengan benar, 3) perintah kepada yang berhutang untuk mendiktekan (apa yang akan ditulis) dengan jujur sesuai dengan apa adanya, 4) diperbolehkan untuk digantikan oleh walinya jika orangyang berhutang itu orang yang akalnya atau kondisinya lemah, 5) perintah untuk mempersaksikan dengan dua orang saksi lelaki (di antaramu); jika tidak ada dua oang lelaki, maka (boleh) seorang lelaki dan dua orang perempuan dari saksi-saksi yang kamu ridai, supaya jika seorang lupa maka yang seorang dapat mengingatkannya, 6) perintah kepada para saksi untuk mau memberi keterangan ketika diperlukan, 7) perintah untuk selalu menulis hutang, baik kecil maupun besar sampai batas waktu membayarnya, 8) perintah untuk tidak saling menyulitkan antara penulis dan saksi, dan 9) perintah untuk bertakwa kepada Allah.

Bagaimana kaitannya dengan pembahasan mengenai kesaksian perempuan, baik tentang nilai kesaksian, cakupan kesaksian, maupun status hukum penggunaan saksi? Mengenai nilai kesaksian perempuan, dalam ayat di atas disebutkan:

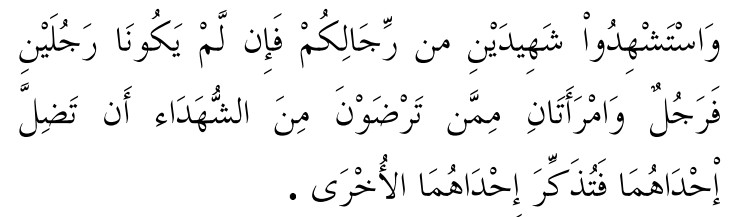

Secara tekstual, bagian ayat ini biasanya diterjemahkan dengan "dan persaksikanlah dengan dua orang saksi dari orang-orang lelaki (di antaramu). Jika tak ada dua oang lelaki, maka (boleh) seorang lelaki dan dua orang perempuan dari saksi-saksi yang kamu ridai, supaya jika seorang lupa maka yang seorang mengingatkannya." Selain itu, bagian ayat tersebut dapat diterjemahkan dengan "Dan persaksikanlah dengan dua orang saksi lelaki (dewasa) di antaramu. Jika tidak ada dua orang lelaki (dewasa), maka seorang lelaki atau dua orang perempuan (dewasa) dari saksi-saksi yang kamu ridai, supaya jika seorang lupa maka yang seorang mengingatkannya." Dengan ini maka saksi dapat terdiri atas dua orang laki-laki (dewasa) atau satu orang laki-laki (dewasa) atau dua orang perempuan (dewasa).

Terjemahan yang kedua ini sebagaimana diusulkan oleh Andi Faisal Bakti, untuk memperhatikan huruf al-waw

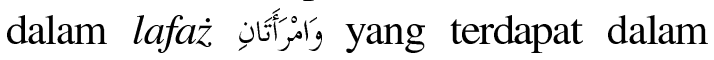
ayat, yang mungkin berarti atau dari pada berarti dan sehingga laki-laki dan perempuan itu dinyatakan sama. ${ }^{29}$ Hal ini dapat dipahami karena huruf al-waw dapat mempunyai beberapa makna dan aneka fungsi. ${ }^{30}$ Di antara maknanya adalah: $a w$ (atau), ${ }^{31} i z$ (karena), ma'a (dengan dan beserta), rubba (kadang-kadang). Adapun beberapa fungsinya adalah: al-hīa (sedangkan dan padahal), al-isti'nāf (permulaan), qasam (demi/sumpah), dan harf al-'atf. ${ }^{32}$

Bagaimana para ulama dan cendekiawan memahami ayat di atas kaitannya dengan kesaksian perempuan? Sebagaimana telah dinyatakan pada bagian sebelumnya bahwa jika ayat tersebut dipahami secara tekstual, maka disimpulkan bahwa nilai kesaksian perempuan adalah separuh kesaksian lakilaki. Akan tetapi, jika ditafsirkan secara kontektual, maka kesaksian perempuan sama dengan kesaksian laki-laki. Padahal, dengan model pemaknaan kedua sebagaimana yang telah diketengahkan di atas, secara tekstual pun bisa dikatakan bahwa nilai kesaksian perempuan bisa "sama" dengan kesaksian laki-laki.

Selanjutnya, dalam bidang apa saja kesaksian perempuan? Ayat 282 surah alBaqarah memang berbicara tentang transaksi mu'amalah hutang piutang, sehingga kesaksian perempuan dalam hal yang berhubungan dengan harta benda 
tidak diragukan lagi keabsahannya. Oleh karena itu, para ulama sepakat akan kebolehannya mengenai hal ini. Sedangkan dalam bidang lainnya, seperti dalam masalah h̆uqūq al-abdān, hudūd, dan qișās ulama berbeda pendapat, sebagaimana yang telah dikemukakan pada bagian sebelumnya.

Lalu, bagaimana dengan hukum penggunaan saksi? Dalam ayat di atas

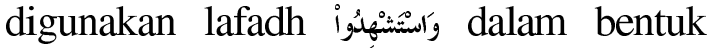
kata kerja perintah ('amr), yang menurut salah satu kaidah bahwa الاصل ف الاهر للوجوب (pada dasarnya suatu perintah menunjukkan hukum wajib dilaksanakan), kecuali ada indikasi atau dalil yang menunjukkan lainnya. Berdasarkan ayat di atas penggunaan saksi untuk transaksi hutang piutang bisa dipahami wajib hukumnya.

b. Mengadakan Saksi Ketika Berwasiat

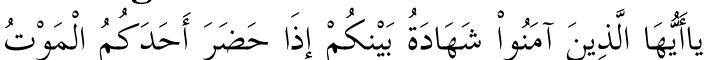

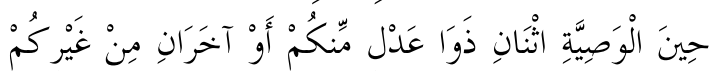

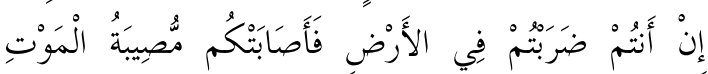

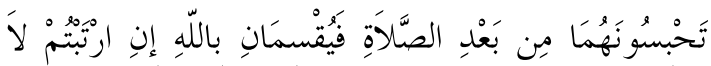

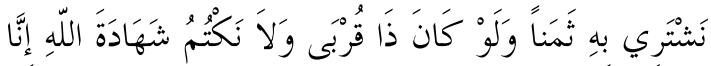

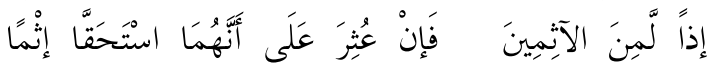

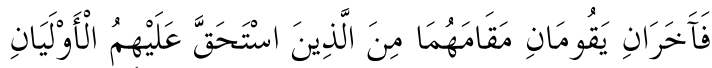

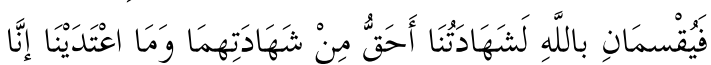

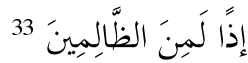

Ayat 106 surah al-Māidah ini mengandung tuntunan bahwa jika salah seorang yang beriman menghadapi kematian, sedang dia akan berwasiat, maka hendaklah (wasiat itu) disaksikan oleh dua orang yang adil di antara kamu, atau dua orang yang berlainan agama dengan kamu, jika kamu dalam perjalanan di muka bumi lalu kamu ditimpa bahaya kematian. Saksi dalam ayat ditekankan pada sifat keadilanya (mempunyai integritas), bukan pada jenis kelaminnya. Oleh karena itu, sekalipun menggunakan

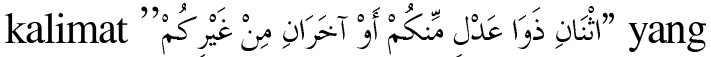
tampaknya menunjukkan muźakkar (laki- laki), bisa berarti tidak hanya terbatas pada laki-laki, tetapi dapat juga saksi perempuan, karena dalam bahasa Arab, kata-kata yang berbentuk muźakkar dapat mencakup laki-laki dan perempuan.

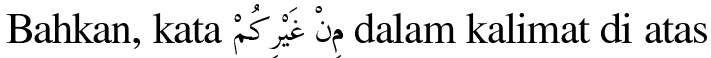
bisa dipahami saksi non muslim (jika mereka adil). Dengan demikian, saksi dalam wasiat, ditekankan kepada orang yang mempunyai sifat adil sehingga bisa laki-laki dan bisa perempuan, bahkan juga bisa juga non muslim, sebagaimana sabab al-nuzūl ayat ini. ${ }^{34}$

Bagaimana dengan cakupan kesaksian dan hukum kesaksian perempuan dalam ayat di atas? Dengan melihat sabab al-nuzūl-nya, ayat ini berbicara tentang wasiat harta benda, sehingga dapat menguatkan pendapat bahwa dalam hal yang menyangkut harta benda tidak ada perselisihan di kalangan ulama tentang kebolehannya. Adapun hukum mempersaksikan wasiat dalam ayat di atas, sekalipun menggunakan kalimat khabar (berita), tetapi yang dimaksudkan adalah perintah. ${ }^{35}$

\section{c. Mengadakan Saksi Ketika}

Menyerahkan Harta Anak Yatim

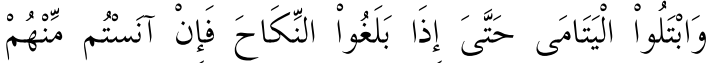

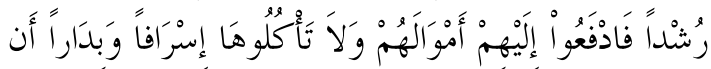

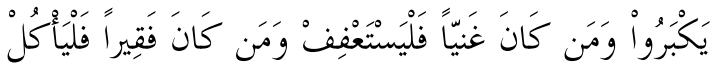

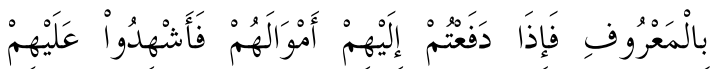
وَكَفَى باللّهِ حَسيباً 36

Ayat ini mengandung hal-hal berikut: 1) perintah kepada para wali anak yatim agar memperhatikan keadaan dan perkembangan anak asuhannya dalam hal kemampuan untuk menggunakan harta serta perintah untuk melatih mereka sampai hampir memasuki usia menikah; 2) perintah kepada para wali untuk menyerahkan harta anak yatim tersebut ketika sudah dipandang mampu untuk memelihara hartanya; 3) larangan kepada para wali untuk makan harta anak yatim, kecuali mereka dalam keadaan miskin dan 
tidak lebih dari batas kepatutan; dan 4) perintah kepada para wali untuk mengadakan persaksian ketika harta itu diserahkan kepada anak yatim (sebagai pemiliknya).

Dalam ayat ini tidak disebut secara eksplisit tentang jenis kelamin saksi sehingga dapat dipahami bahwa saksi tersebut bisa laki-laki dan bisa perempuan; juga, jumlahnyapun tidak disebutkan. Adapun hal yang dipersaksikannya mengenai penyerahan harta anak yatim sehingga dapat memperkuat kesepakatan ulama bahwa perempuan diperbolehkan bersaksi dalam hal yang berkaitan dengan harta benda. Lalu, bagaimana dengan hukum mempersaksikannya? Dalam ayat di atas digunakan kata amr (perintah),

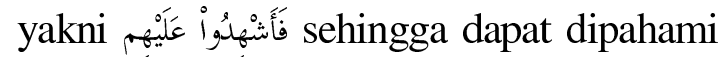
wajib hukumnya, kecuali ada indikasi lain yang menunjukkan lainnya.

Mengenai persaksian yang berkaitan dengan harta, sebagaimana dikemukakan di atas, al-Qur'an menggunakan kata yang beragam. Untuk hutang piutang langsung menyebutkan saksi laki-laki dan atau perempuan, untuk wasiat menggunakan kata dua orang lakilaki yang adil (baik muslim maupun non muslim), dan untuk penyerahan harta anak yatim tidak menyebutkan jenis kelamin dan jumlah saksi. Walau secara tekstual menggunakan kata yang beragam, tetapi dalam masalah ini ulama sepakat akan kebolehan kesaksian perempuan, sekalipun hanya dihargai separuh dari kesaksian laki-laki. Padahal, dengan pembacaan secara tekstualpun nilai kesaksian perempuan bisa dipahami sama dengan kesaksian laki-laki.

\section{Mengadakan Saksi Ketika}

\section{Menceraikan atau Merujuk Istri}

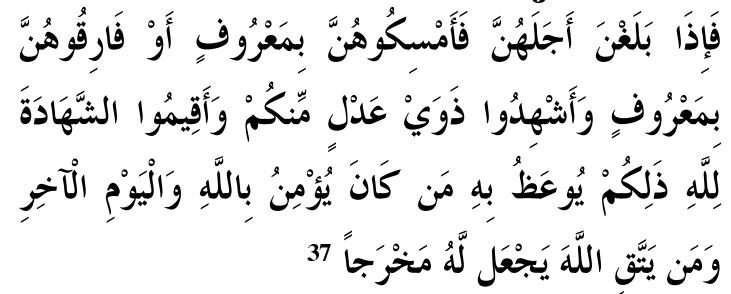

Ayat ini mengandung tuntunan kepada para suami yang sedang "mentalak" istrinya (dalam talak raj' $\grave{l}$ ) dan hampir habis masa 'iddahnya untuk merujuknya atau menceraikannya dengan cara yang ma'rūf. Ayat ini juga memerintahkan kepada para suami untuk mempersaksikan hal yang dilakukannya itu (rujuk ataupun talak) kepada dua orang saksi yang adil dan muslim. Kemudian, diperintahkan pula agar para suami melaksanakan kesaksian secara sungguhsungguh karena Allah.

Bagaimana dengan kesaksian perempuan dalam talak dan rujuk? Ayat

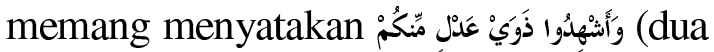
orang laki-laki yang adil dari kalanganmu/muslim), yang bisa jadi dipahami laki-laki. Akan tetapi, jika dipahami bahwa kata yang berbentuk muźakkar bisa mencakup perempuan, maka berarti saksi yang dimaksudkan bisa laki-laki dan bisa juga perempuan. Adapun mengenai hukum mempersaksikan talak dan rujuk, para ulama berbeda pendapat. Abu Hanīfah, misalnya, menyatakan bahwa hukum mempersaksiakan rujuk atau talak itu sunnah, sedangkan menurut Syafi' $1 \overline{1}$ wajib untuk mempersaksikan rujuk dan sunnah untuk talak. ${ }^{38}$ Padahal kalau melihat ayat di atas talak ataupun rujuk sama-sama diperintahkan untuk dipersaksikan. Hal ini dikuatkan dengan hadis Abū Dāwud dan Ibnu Mājah berikut:

$$
\begin{aligned}
& \text { عن عمران بن حُصَين: أنه سُئِل عن الرجل يطلق امرأته } \\
& \text { تم يقع ها و لم يشهد على طلاقها ولا على رجعتها فقال: } \\
& \text { طلَّقتَ لغير سنة، ورجعت لغير سنة، وأشهذْ على طلاقها } \\
& \text { وعلى رجعتها، ولا تَعُدْ } 39
\end{aligned}
$$

Dari hadis di atas jelas bahwa baik untuk talak maupun untuk rujuk harus dipersaksikan dengan dua orang yang adil. 


\section{Saksi yang Berkaitan Dengan Hudūud}

d. Menuduh Istri Zina Harus Dengan 4 Saksi

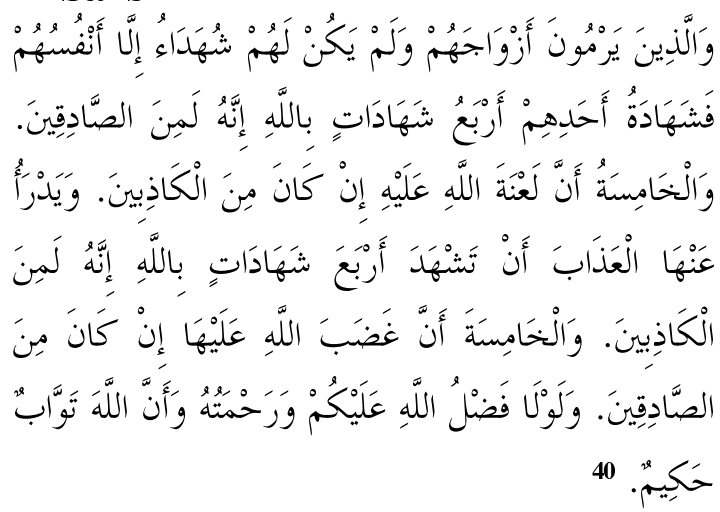

Ayat ini memberikan tuntunan bahwa orang yang menuduh istrinya tidak mempunyai saksi kecuali dirinya sendiri, maka orang tersebut dapat bersumpah dengan nama Allah sebanyak empat kali bahwa dia adalah orang yang benar. Kemudian, ditambah dengan sumpah yang kelima, bahwa laknat Allah atasnya, jika ia berdusta. Sebaliknya, jika apa yang dituduhkan kepada istrinya itu tidak benar, maka si istri dapat menghindari hukuman zina dengan cara sebagaimana yang dilakukan oleh suami, yakni bersumpah dengan nama Allah sebanyak empat kali bahwa suaminya itu bohong, kemudian, ditambah dengan sumpah yang kelima bahwa murka Allah atas dirinya, jika suaminya benar.

Kedua suami dan istri dalam ayatayat di atas sama-sama dapat melakukan sumpah sebanyak empat kali. Kalau nilai kesaksian perempuan separuh dari nilai kesaksian laki-laki, seharusnya istri perlu bersumpah sebanyak delapan kali untuk menyanggah tuduhan suaminya. Dengan demikian, dapat disimpulkan bahwa kesaksian perempuan dalam hal ini (hukum had) dapat diterima dengan nilai yang sama dengan laki-laki. Hal ini jelas bertentangan dengan pendapat ulama yang menyatakan bahwa kesaksian perempuan tidak diterima dalam hal-hal yang berkaitan dengan ḩudūd. Kalaupun diterima, sebagaimana pendapat kalangan
Żahirī kesaksian perempuan hanya dihargai separuh dari kesaksian laki-laki, padahal Nabi menerima kesaksian seorang perempuan yang mengaku diperkosa oleh seorang laki-laki. ${ }^{41}$

\section{e. Mencemarkan Nama Baik Tanpa \\ Saksi Didera 80 Kali}

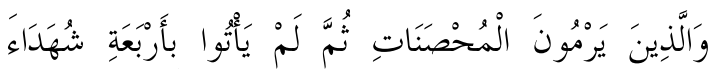

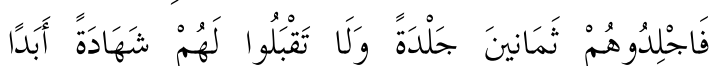

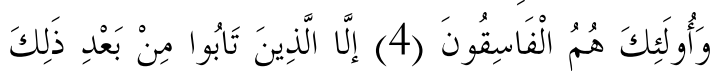

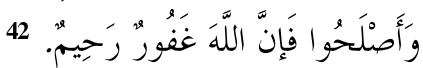

Ayat ini mengandung peringatan tentang sangsi hukum terhadap penuduh zina tanpa disertai dengan empat orang saksi, maka ia dihukum cambuk delapan puluh kali, tidak diterima kesaksiannya, dan mereka dianggap sebagai orang-orang yang fasik, kecuali jika mereka bertaubat (Q.S. al-Nūr (24) : 4-5).

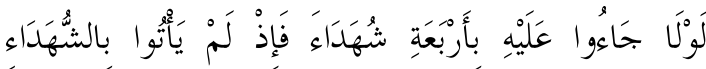

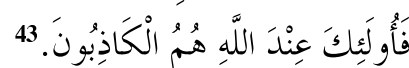

Kalau orang yang menuduh zina itu memang benar, mereka dituntut untuk mendatangkan empat orang saksi. Jika tidak mendatangkan saksi maka mereka itulah orang-orang yang bohong (sekalipun bisa jadi mereka sebenarnya tidak berdusta) (Q.S. al-Nūr (24) : 13).

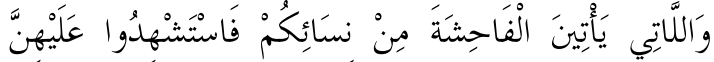

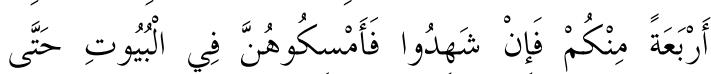

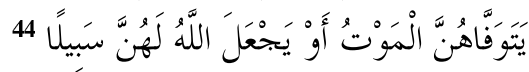

Ayat ini menjelaskan bahwa seorang yang menuduh perempuan melakukan perbuatan fāhisyah harus disaksikan oleh empat orang saksi. Jika tuduhan tersebut benar dengan disaksikan oleh empat orang saksi, maka perempuan itu dihukum kurungan atau sampai Allah memberikan jalan lainnya.

Lalu, bagaimana dengan kesaksian perempuan dalam masalah hud $\bar{u} d$ ini? Dalam ketiga ayat di atas digunakan kata-

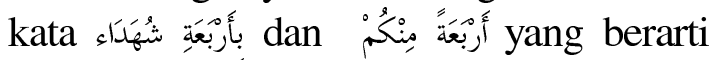
empat saksi laki-laki, kecuali jika 
dipahami bahwa kata-kata yang menggunakan bentuk muźakkar dapat berarti laki-laki dan perempuan. Mengenai hukum mendatangkan saksi untuk pencemaran nama baik tentulah wajib hukumnya, karena kalau tidak, penuduhnya akan dikenai hukuman jilid.

\section{Menegakkan Keadilan}

\section{f. Menjadi Saksi yang Adil}

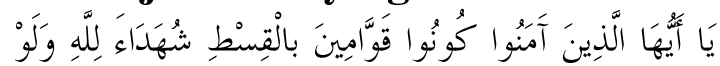

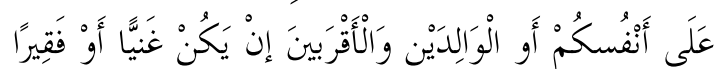

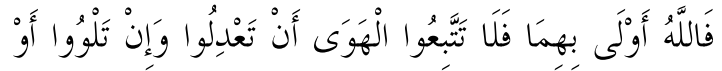

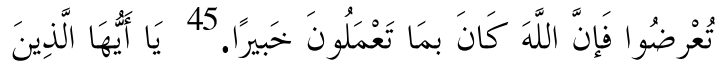

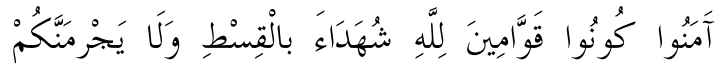

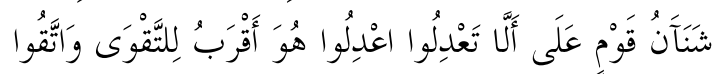

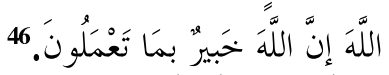

Kedua ayat di atas merupakan perintah kepada orang yang beriman untuk menjadi penegak keadilan karena Allah dan menjadi saksi yang adil, tidak mengikuti hawa nafsu, sekalipun terhadap diri sendiri, keluarga, dan kerabat bagaimanapun keadannya. Bahkan diingatkan pula bahwa ketidaksukaan tangan, dan kaki) mereka yang berperan menyebarkan isu bohong (dengan menuduh zina terhadap perempuan baik-baik) akan menjadi saksi terhadap apa yang mereka lakukan ketika di dunia. Dalam ayat ini juga menggunakan kata berbentuk muźakkar walaupun yang dituju tentunya bukan hanya laki-laki, tetapi juga perempuan.

\section{h. Reward Bagi Saksi yang Jujur}

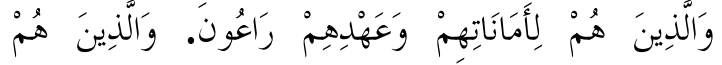

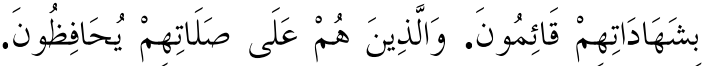

$$
\begin{aligned}
& \text { أُوَلَئكَكَ فِي جَنَّاتِ مُكْرَمْونَ. }
\end{aligned}
$$

Dalam ayat ini dikemukakan janji surga bagi beberapa kalangan, yaitu: orang-orang yang amanah, orang-orang yang memberikan kesaksian dengan benar, dan orang-orang yang memelihara terhadap suatu kaum jangan sampai mendorong orang yang beriman untuk bersikap tidak adil. Kemudian, diingatkan untuk bertakwa kepada Allah, karena Allah Maha Mengetahui terhadap apa yang dikerjakan. Kedua ayat di atas memang menggunakan kata berbentuk

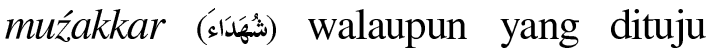
tentunya bukan hanya laki-laki, tetapi juga mencakup perempuan.

Adapun mengenai dalam hal apakah orang yang beriman harus menegakkan keadilan? Sebagaimana tampak dalam ayat di atas yang bentuk 'āmm, tentunya dalam segala bidang seperti dalam hal yang berkaitan dengan harta benda, hak-hak badan, hudūd, dan qișāș. Mengenai hukum menegakkan keadilan adalah wajib sebagaimana dapat dipahami dari bentuk perintah dari ayat di atas.

\section{g. Anggota tubuh sendiri akan menjadi saksi

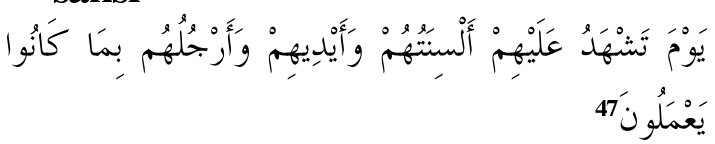

Ayat ini menceritakan bahwa kelak di hari kiamat anggota tubuh (lidah, shalat. Walaupun dalam ayat di atas digunakan kata yang berbentuk muźakkar yang dituju tentunya bukan hanya lakilaki, tetapi juga perempuan.

\section{G. Kesimpulan}

Dari uraian di atas dapat disimpulkan hal-hal berikut: pertama, nilai kesaksian perempuan bisa sama dengan nilai kesaksian laki-laki baik teks ayat yang ada dibaca secara tekstual maupun secara kontekstual. Kedua, kesaksian perempuan dalam Islam tidak hanya terbatas pada hal-hal yang berkaitan dengan harta benda seperti transaksi hutang piutang, wasiat, dan penyerahan harta anak yatim, tetapi juga mencakup hal lainnya, seperti huudūd dan qișasș. Ketiga, hukum mempersaksikan dalam hal yang berkaitan dengan harta benda, talak dan rujuk, tuduhan berbuat zina dan 
pencemaran nama baik, serta penegakan keadilan adalah wajib, karena secara

\section{Catatan Akhir}

1 Abī al-Ḥusayn Aḥmad bin Fāris bin Zakariyya, taḥq̄iq 'Abd al-Salām Muhammad Hārūn, http://www.awu-dam.org. (T.t.p.: Ittihād al-Kitāb al-'Arb, 2002M./1423H.), III: 172.

${ }^{2}$ Al-Rāghib al-Așfihān̄i, Mu'jam Mufradāt Alfā̇̇ al-Qur'ān (Beirut: Dār al-Fikr lial-T,ibā'ah wa al-Nasyr wa al-Tawzī', t.t), hlm. 274-275.

Al-Jurjān̄ī, al-Ta'rīfāt (CD alMaktabah al-Syāmilah), I: 42.

4 Umul Baroroh menulis pandangan kelompok klasik dan feminis mengenai saksi perempuan. Simak dalam Umul Baroroh, "Kesaksian Perempuan Separuh Laki-laki?," dalam Pemahaman Islam dan Tantangan Keadilan Jender (Yogyakarta: Gama Media, 2002), hlm. 75.

${ }^{5}$ Yunahar Ilyas meneliti penafsiran para mufasir (al-Zamakhsyarī, al-Alūs̄i, dan Sa'īd alHawā) dan feminis muslim (Asghar Ali Engineer, Riffat Hassan, dan Aminah Wadud Muhsin) dengan menggunakan pendekatan teologis filosofis. Lihat Yunahar Ilyas, Feminisme dalam Kajian Tafsir al-Qur'an Klasik dan Kontemporer (Yogyakarta: Pustaka Pelajar, 1997), hlm. 148.

${ }^{6}$ Zaitunah Subhan meneliti pandangan mufasir Indonesia dan mufasir klasik. Lihat dalam Zaitunah Subhan: Tafsir Kebencian: Studi Bias Gender dalam Tafsir al-Qur'an (Yogyakarta: LKis, 1999), hlm. 180.

Al-Baqarah (2): 282. "Dan persaksikanlah dengan dua orang saksi dari orang-orang lelaki (di antaramu). Jika tak ada dua oang lelaki, maka (boleh) seorang lelaki dan dua orang perempuan dari saksi-saksi yang kamu ridhai, supaya jika seorang lupa maka yang seorang mengingatkannya."

8 Muhammad ibn Ismā'ìl al- Bukhārī, Şah̄̄h al-Bukhārīi (Bandung: Syirkah al-Ma'ārif, t.t.), 'Bāb Syahādah al-Nisā',", no. 2515, vol. 2, hlm. 103.

${ }^{9}$ Adanya banyak kemungkinan dalam memahami hadis ini dibahas dengan panjang lebar oleh Abu Syuqqah dalam bukunya Jati Diri Wanita menurut al-Qur'ān dan Hadis, terj. Mujiyo (Bandung: al-Bayan, 1993), hlm. 279297.

10 Subhan, Tafsir Kebencian, hlm. 121. Kesimpulan yang sama juga dikemukan oleh Ilyas, Feminisme, hlm. 130.

${ }^{11} \mathrm{Di}$ antara contohnya adalah diketengahkan oleh mufasir al-Alūsi, lihat Abū al- umum teks al-Qur'an menggunakan kata dalam bentuk 'amr.

Fad'l Syihāb al-Dīn al-Sayyaid Maĥmūd al-Alūsī, Rūh al-Ma'ānī fì Tafsīr al-Qur'an al-'Aạ̄m wa alSab' al-Mašāñ̄ (ttp.: Dār al-Fikr, t.t), II: 58.

${ }^{12}$ Hal ini sebagaimana di kemukakan oleh Amina Wadud Muhsin, Qur'an and Woman Kuala Lumpur: Fajar bakti, 1992), hlm. 85-86.

${ }^{13} \mathrm{Di}$ antara yang berpendapat demikian adalah Asghar Ali Engineer, Hak-Hak Perempuan dalam Islam, terj. Farid Wajidi dan Cici Farkha Assegaf (Yogyakarta: Yayasan Bentang Budaya, 19940), hlm. 87.

${ }^{14}$ Subhan, Tafsir Kebencian, hlm. 121.

${ }^{15}$ Ilyas, Feminisme, hlm. 131-132.

${ }^{16}$ Ibid., hlm151.

${ }^{17}$ Abū 'Umar Yūsuf al-Qurțubī, al-Kāfì fi Fiqh Ahl al-Madīnah, taĥ̀īq Muhammad Amīn, cet. 2 (Riyād': Maktabah al-Riyād' al-Ĥadī̌̌ah, t.t.), II: 906.

18 Muhammad al-Khațīib al-Syarbīn̄̄, Mughnī al-Muhtāj (ttp.: Dār al-Fikr, 1398H.), IV: 441.

${ }^{19}$ Apabila mereka telah mendekati akhir 'iddahnya, maka rujukilah mereka dengan baik atau lepaskanlah mereka dengan baik dan persaksikanlah dengan dua orang saksi yang adil di antara kamu dan hendaklah kamu tegakkan kesaksian itu karena Allah. Demikianlah diberi pengajaran dengan itu orang yang beriman kepada Allah dan hari akhirat. Barang siapa yang bertakwa kepada Allah niscaya Dia akan mengadakan baginya jalan ke luar.

20 Al-Imām Muhammad bin 'Al alSyawkān̄i, Nayl al-Awțār (Beirut: Dār al-Kutb al'Ilmiyyah, 1403 H.), VI: 125-126.

21 Fakhr al-Dīn al-Zaila'̄i, Tabyīn alĤaqaiq Syarh Kanz al-Daqāiq (ttp.: Dār alMa'rifah li al-T,ibā'ah, t.t.) IV: 209.

${ }^{22}$ Muhammad Quraish Shihab, Tafsir alMishbāh: Pesan, Kesan, dan Keserasian alQur'a, (Ciputat: Lentera Hati, 2000), II: 357.

${ }^{23}$ Ibid.

${ }^{24}$ Abū al-Walīd Muhammad ibn Aḥmad ibn Muhammad in Aḥmad ibn Rusyd, Bidayah alMujtahid wa-Nihāyah al-Muqtașid (Semarang: Maktabah Usaha Keluarga, t.t.), II: 348.

${ }^{25}$ Baca dalam Fakhr al-Dīn al-Rāzì, Mafātīh al-Ghayb (CD al-Maktabah al-Syāmilah), IV: 48

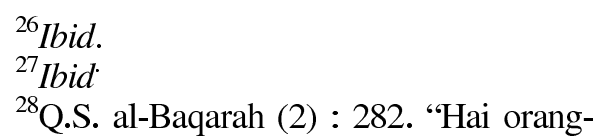
orang yang beriman, apabila kamu bermu'amalah tidak secara tunai untuk waktu yang ditentukan, hendaklah kamu menuliskannya. Dan hendaklah seorang penulis di antara kamu menuliskannya dengan benar. Dan janganlah penulis enggan 
menuliskannya sebagaimana Allah mengajarkannya, maka hendaklah ia menulis, dan hendaklah orang yang berhutang itu mengimlakkan (apa yang akan ditulis itu), dan hendaklah ia bertakwa kepada Allah Tuhannya, dan janganlah ia mengurangi sedikitpun daripada hutangnya. Jika yang berhutang itu orang yang lemah akalnya atau lemah (keadaannya) atau dia sendiri tidak mampu mengimlakkan, maka hendaklah walinya mengimlakkan dengan jujur. Dan persaksikanlah dengan dua orang saksi dari orang-orang lelaki (di antaramu). Jika tak ada dua orang lelaki, maka (boleh) seorang lelaki dan dua orang perempuan dari saksi-saksi yang kamu ridhai, supaya jika seorang lupa maka yang seorang mengingatkannya. Janganlah saksi-saksi itu enggan (memberi keterangan) apabila mereka dipanggil; dan janganlah kamu jemu menulis hutang itu, baik kecil maupun besar sampai batas waktu membayarnya. Yang demikian itu, lebih adil disisi Allah dan lebih dapat menguatkan persaksian dan lebih dekat kepada tidak (minimbulkan) keraguanmu, (tulislah mu'amalahmu itu), kecuali jika mu'amalah itu perdagangan tunai yang kamu jalankan di antara kamu, maka tidak ada dosa bagi kamu, (jika) kamu tidak menulisnya. Dan persaksikanlah apabila kamu berjual beli; dan janganlah penulis dan saksi saling sulit-menyulitkan. Jika kamu lakukan (yang demikian), maka sesungguhnya hal itu adalah suatu kefasikan pada dirimu. Dan bertakwalah kepada Allah; Allah mengajarmu; dan Allah Maha Mengetahui segala sesuatu".

${ }^{29}$ Andi Faisal Bakti, "Commucation and Dakwah: Religious Learning Groups and Their Role in the Protection of Islamic Human Security and Rights for Indonesian Civil Society," dalam Comaparative Education, Terrorism and Human Security: From Critical Pedagogy to Peace Building?, ed. Wayne Nelles (New York: Palgrave Macmillan, 2003), hlm.119.

${ }^{30}$ Lihat Naqiyah Mukhtar, Kontroversi Presiden Perempuan: Studi terhadap Pandangan Mufasir dan Media di Indonesia (Purwokerto: STAIN Purwokerto Press, 2009), hlm. 42.

31 "Aw mempunyai tiga macam makna: taqsīm (pembagian) misalnya الكلمة اسمّ، وفعلٌ، وحرف),

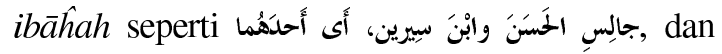

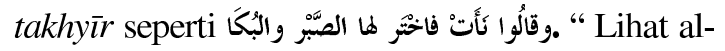
Fairūz Abādī, Bașā̄ir Żaw̄ al-Tamȳ̄z fì Lațāif al-Kitāb al-'Azīz (CD al-Maktabah al-Syāmilah), I: 1527. Lihat juga Mukhtar, Kontroversi Presiden Perempuan, hlm. 42-43.

${ }^{32}$ Mengenai informasi aneka ragam arti dan fungsi $a l-w \bar{a} w u$ bisa dilihat dalam al-Fairūz Ābādī, Bașāir I: 1526-1528.
33 Q.S. al-Ma`idah (5):106-107. "Hai orang-orang yang beriman, apabila salah seorang kamu menghadapi kematian, sedang dia akan berwasiat, maka hendaklah (wasiat itu) disaksikan oleh dua orang yang adil di antara kamu, atau dua orang yang berlainan agama dengan kamu, jika kamu dalam perjalanan dimuka bumi lalu kamu ditimpa bahaya kematian. Kamu tahan kedua saksi itu sesudah sembahyang (untuk bersumpah), lalu mereka keduanya bersumpah dengan nama Allah, jika kamu ragu-ragu: "(Demi Allah) kami tidak akan membeli dengan sumpah ini harga yang sedikit (untuk kepentingan seseorang), walaupun dia karib kerabat, dan tidak (pula) kami menyembunyikan persaksian Allah; sesungguhnya kami kalau demikian tentulah termasuk orang-orang yang berdosa". 'Jika diketahui bahwa kedua (saksi itu) memperbuat dosa, maka dua orang yang lain di antara ahli waris yang berhak yang lebih dekat kepada orang yang meninggal (memajukan tuntutan) untuk menggantikannya, lalu keduanya bersumpah dengan nama Allah: "Sesungguhnya persaksian kami lebih layak diterima daripada persaksian kedua saksi itu, dan kami tidak melanggar batas, sesungguhnya kami kalau demikian tentulah termasuk orang-orang yang menganiaya diri sendiri".

${ }^{34}$ Salah satu riwayat tersebut adalah apa yang diriwayatkan melalui Ibn 'Abbas yang menyebut bahwa ada dua orang, Tamim ad-Dārī dan 'Ad̄̄ Ibn Zaid, yang seringkali mondarmandir ke Mekah. Suatu ketika mereka berdua ditemani oleh seorang pemuda Quraisy dari Bani Sahm, bernama Budail Ibn Ab̄̄ Maryam menuju ke Syam. Dalam perjalanan pemuda itu jatuh sakit dan meninggal dunia, di suatu daerah yang tidak berpenduduk muslim. Sebelum wafatnya ia berwasiat kepada Tamim dan 'Ādi agar menyerahkan harta peninggalannya kepada keluarganya, dengan menyertakan sepucuk surat yang menjelaskan tentang barang-barang yang ditinggalkannya. Salah satu di antaranya adalah berupa tempat (wadah) yang terbuat dari ukiran perak berwarna-warni. Tamīm dan 'Ādī yang tidak mengetahui tentang surat itu menjual wadah tersebut dan menyerahkan sisa harta wasiat Budail kepada keluarganya. Ketika keluarga Budail menanyakan tentang wadah yang terbuat dari perak itu, Tamīm dan 'Ādi mengingkarinya, kemudian Nabi saw menjumpai keduanya. Tidak lama kemudian, wadah tersebut ditemukan pada seorang kaum dari penduduk Makkah, yang mengaku membelinya dari Tamim dan 'Adi. Keluarga Budail datang kepada Nabi saw dan bersumpah bahwa kesaksian mereka lebih wajar diterima dari pada sumpah Tamīm dan 'Ādi. Kemudian Rasul membenarkan dan memberikan 
wadah tersebut kepada keluarga yang meninggal itu. Dalam sebuah riwayat diinformasikan bahwa ' $\bar{d}$ di mengembalikan uang harga wadah yang dijualnya kepada ahli waris yang berhak menerimanya.

35 Jalāl al-Dīn al- Maĥallī dan Jalāl alDīn al-Suyūțī, Tafsīr al-Jalālain (CD alMaktabah al-Syāmilah), hlm. 125.

${ }^{36}$ Q.S. al-Nisa' (4): 6. "Dan ujilah anak yatim itu sampai mereka cukup umur untuk kawin. Kemudian jika menurut pendapatmu mereka telah cerdas (pandai memelihara harta), maka serahkanlah kepada mereka harta-hartanya. Dan janganlah kamu makan harta anak yatim lebih dari batas kepatutan dan (janganlah kamu) tergesa-gesa (membelanjakannya) sebelum mereka dewasa. Barang siapa (di antara pemelihara itu) mampu, maka hendaklah ia menahan diri (dari memakan harta anak yatim itu) dan barangsiapa yang miskin, maka bolehlah ia makan harta itu menurut yang patut. Kemudian apabila kamu menyerahkan harta kepada mereka, maka hendaklah kamu adakan saksi-saksi (tentang penyerahan itu) bagi mereka. Dan cukuplah Allah sebagai Pengawas (atas persaksian itu)".

37 Q.S. al-Thalaq (65): 2."Apabila mereka telah mendekati akhir masa 'iddahnya, maka rujukilah mereka dengan baik atau lepaskanlah mereka dengan baik dan persaksikanlah dengan dua orang saksi yang adil di antara kamu dan hendaklah kamu tegakkan kesaksian itu karena Allah. Demikianlah diberi pengajaran dengan itu orang yang beriman kepada Allah dan hari akhirat. Barangsiapa bertakwa kepada Allah niscaya Dia akan mengadakan baginya jalan keluar.

${ }^{38}$ Al-Rāzì, Mafātīĥh al-Ghayb, hlm. 558.

${ }^{39}$ Abū Dāwūd Sulaymān ibn al-Asy'aš

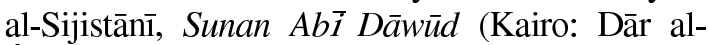
Ĥadī̌s, 1999). Hadis no. 2186.

${ }^{40}$ Q.S. al-Nur (24): 6-10. 'Dan orangorang yang menuduh istrinya (berzina), padahal mereka tidak ada mempunyai saksi-saksi selain diri mereka sendiri, maka persaksian orang itu ialah empat kali bersumpah dengan nama Allah, sesungguhnya dia adalah termasuk orang-orang yang benar. Dan (sumpah) yang kelima: bahwa laknat Allah atasnya, jika dia termasuk orang-orang yang berdusta.Istrinya itu dihindarkan dari hukuman oleh sumpahnya empat kali atas nama Allah sesungguhnya suaminya itu benar-benar termasuk orang-orang yang dusta,dan (sumpah) yang kelima: bahwa laknat Allah atasnya jika suaminya itu termasuk orang-orang yang benar. Dan andai kata tidak ada karunia Allah dan rahmatNya atas dirimu dan (andai kata) Allah bukan Penerima Taubat lagi Maha Bijaksana, (niscaya kamu akan mengalami kesulitan-kesulitan)."
${ }^{41}$ Baca riwayat 'Alqamah bin Wā'il dari bapaknya dalam Al-Sijistānī, Sunan Abi Dāwūd IV: 1872.

${ }^{42}$ Q.S. an-Nur (24): 4-5. 'Dan orangorang yang menuduh wanita-wanita yang baikbaik (berbuat zina) dan mereka tidak mendatangkan empat orang saksi, maka deralah mereka (yang menuduh itu) delapan puluh kali dera, dan janganlah kamu terima kesaksian mereka buat selama-lamanya. Dan mereka itulah orang-orang yang fasik, kecuali orang-orang yang bertaubat sesudah itu dan memperbaiki (dirinya), maka sesungguhnya Allah Maha Pengampun lagi Maha Penyayang".

43 Q.S. al-Nur (24): 13. "Mengapa mereka (yang menuduh itu) tidak mendatangkan empat orang saksi atas berita bohong itu? Oleh karena mereka tidak mendatangkan saksi-saksi maka mereka itulah pada sisi Allah orang-orang yang dusta."

${ }^{44}$ Q.S. al-Nisa' (4): 15. 'Dan (terhadap) para wanita yang mengerjakan perbuatan keji, hendaklah ada empat orang saksi di antara kamu (yang menyaksikannya). Kemudian apabila mereka telah memberi persaksian, maka kurunglah mereka (wanita-wanita itu) dalam rumah sampai mereka menemui ajalnya, atau sampai Allah memberi jalan yang lain kepadanya".

45 Q.S. al-Nisa' (4): 135. "Wahai orangorang yang beriman, jadilah kamu orang yang benar-benar penegak keadilan, menjadi saksi karena Allah biar pun terhadap dirimu sendiri atau ibu bapak dan kaum kerabatmu. Jika ia kaya atau pun miskin, maka Allah lebih tahu kemaslahatannya. Maka janganlah kamu mengikuti hawa nafsu karena ingin menyimpang dari kebenaran. Dan jika kamu memutar balikkan (kata-kata) atau enggan menjadi saksi, maka sesungguhnya Allah adalah Maha Mengetahui segala apa yang kamu kerjakan."

46 Q.S. al-Ma'idah (5) : 8. "Hai orangorang yang beriman, hendaklah kamu jadi orangorang yang selalu menegakkan (kebenaran) karena Allah, menjadi saksi dengan adil. Dan janganlah sekali-kali kebencianmu terhadap sesuatu kaum, mendorong kamu untuk berlaku tidak adil. Berlaku adillah, karena adil itu lebih dekat kepada takwa. Dan bertakwalah kepada Allah, sesungguhnya Allah Maha Mengetahui apa yang kamu kerjakan."

47 Q.S. al-Nur (24) : 24. "Pada hari (ketika), lidah, tangan, dan kaki mereka menjadi saksi atas mereka terhadap apa yang dahulu mereka kerjakan"

${ }^{48}$ Q.S. al-Ma'arij (70): 33. "Dan orangorang yang memelihara amanat-amanat (yang dipikulnya) dan janjinya. Dan orang-orang yang 
memberikan kesaksiannya. Dan orang-orang yang memelihara shalatnya. Mereka itu (kekal) di syurga lagi dimuliakan."

\section{DAFTAR PUSTAKA}

Abū Syuqqah. Jati Diri Wanita menurut al-Qur'ān dan Hadis, terj. Mujiyo dari Taĥhrì al-Mar'ah fi 'Ashr alRisālah. Bandung: al-Bayan, 1993.

Al-Alūsi, Abū al-Fad'l Syihāb al-Dīn alSayyaid Maĥmūd. Rūh al-Ma'ān̄̄ fi Tafsìr al-Qur'an al-'Ażìm wa alsab' al-Mašānī. t.tp.: Dār al-Fikr, t.t.

Al-Aşfihān̄̄, Al-Rāghi., Mu'jam Mufradāt Alfā̇̇ al-Qur'ān. Beirut: Dār al-Fikr li-al-T,ibā'ah wa alNasyr wa al-Tawz $\overline{\mathbf{1}}$, t.t.

Muhammad ibn Ismā'ỉl al-Bukhārī. Șah̄̄h al-Bukhāri. Bandung: Syirkah alMa'ārif, t.t.

Al-Fairūzābādī. Bașāir Żawī al-Tamyı̄z fì Lațāif al-Kitāb al-'Azīz. CD alMaktabah al-Syāmilah.

'Ali, 'Abdullah Yusuf. The Holy Qur'ān: Text Translation \& Commentary. Maryland: Amana Corporation, 1989.

Al-Jurjānī. al-Ta'rīfāt. CD al-Maktabah al-Syāmilah.

Al-Maĥallì, Jalāl al-Dīn dan Jalāl al-Dīn al-Suyūțī. Tafsīr al-Jalālayn. CD al-Maktabah al-Syāmilah.

Al-Qurțubī, Abū 'Umar Yūsuf. al-Kāfi fi Fiqh Ahl al-Madinah, taḥīq Muhammad Amīn. Riyāḍ: Maktabah al-Riyād' al-Ĥadīšah, t.t.

Al-Rāzī, Fakhr al-Dīn. Mafātīh al-Ghaib. CD al-Maktabah al-Syāmilah.

Al-Sijistānī, Abū Dāwūd Sulaimān bin alAsy'aš. Sunan Abi Dāwud. Cairo: Dār al-Ĥad̄̄̌s, 1999.

Al-Syarbīnī, Muḥammad al-Khațīb. Mughnī al-Muhtāj. Ttp.: Dār alFikr, 1398H.
Al-Syawkānī, Muḥammad ibn 'Alī. Nayl al-Awțār. Beirut: Dār al-Kutb al'Ilmiyyah, 1403H.

Al-Zayla'̄̄, Fakhr al-Dīn. Tabyīn alHaqāiqSyarh Kanz al-Daqāiq. Ttp.: Dār al-Ma'rifah al-Țibā'ah, t.t.

Bakti, Andi Faisal. "Commucation and Dakwah: Religious Learning Groups and Their Role in the Protection of Islamic Human Security and Rights for Indonesian Civil Society," dalam Comaparative Education, Terrorism and HumanSecurity: From Critical Pedagogy to Peace Building?, ed. Wayne Nelles. New York: Palgrave Macmillan, 2003.

Baroroh, Umul. "Kesaksian Perempuan Separuh Laki-laki?," dalam Pemahaman Islam dan Tantangan Keadilan Jender.Yogyakarta: Gama Media, 2002.

Engineer, Asghar Ali. Hak-Hak Perempuan dalam Islam, terj. Farid Wajidi dan Cici Farkha Assegaf. Yogyakarta: Yayasan Bentang Budaya, 1994.

Ibn Rusyd, Abū al-Walīd Muhammad ibn Aḥmad ibn Muḥammad ibn Ahmad. Bidayah al-Mujtahid waNihāyah al-Muqtašid. Semarang: Maktabah Usaha Keluarga, t.t.

Ilyas, Yunahar. Feminisme dalam Kajian Tafsir al-Qur'an Klasik dan Kontemporer. Yogyakarta: Pustaka Pelajar, 1997.

Muhsin, Amina Wadud. Qur'an and Woman. Kuala Lumpur: Fajar Bakti, 1992.

Mukhtar, Naqiyah. Kontroversi Presiden Perempuan: Studi terhadap Pandangan Mufasir dan Media di Indonesia. Purwokerto: STAIN Purwokerto Press, 2009.

Shihab, M. Quraish. Perempuan: dari Cinta sampai Seks dari Nikah 
Mut'ah sampai Nikah Sunnah, dari Bias Lama sampai Bias Baru. Tangerang: Lentera Hati, 2005.

Shihab, M. Quraish. Tafsir al-Mishbāh: Pesan, Kesan dan Keserasian alQur'an, Ciputat: Lentera Hati, 2000.
Subhan, Zaitunah. Tafsir Kebencian: Studi Bias Gender dalam Tafsir al-Qur'an. Yogyakarta: LKis, 1999.

Tim Departemen Agama. Tafsir alQur'an Karim. Jakarta: Menara Kudus/Citra Utama, 1996.

Yunus, Mahmud. Tafsir Qur'an Karim. Jakarta: Hidakarya Agung, 1993. 


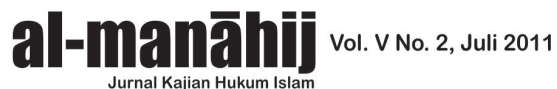

